\title{
The re-making of the English working class?
}

\author{
MARC W. STEINBERG
}

University of Michigan

\begin{abstract}
Roundhead, Leveller, and Cavalier, Chartist and Anti-Corn Law Leaguer, were not [Pavlovian] dogs; they did not salivate their creeds to economic stimuli; they loved and hated, argued, thought, and made moral choices. Economic changes impel changes in social relationships, in relations between real men and real women; and these are apprehended, felt, reveal themselves in feelings of injustice, frustration, aspirations for social change; all is fought out in human consciousness, including the moral consciousness. If this were not so, [people] would be - not dogs - but ants, adjusting their society to the upheavals in the terrain. But [people] make their own history: they are part agents, part victims: it is precisely the element of agency which distinguishes them from beasts, which is the human part ... and which is the business of our consciousness to increase.
\end{abstract}

E. P. Thompson ${ }^{1}$

In the quarter-century since the publication of Thompson's remarkable tome, The Making of the English Working Class, it and his subsequent works have informed the historical vision of a generation of social scientists in Britain and in the United States. These works have sparked political and academic controversy. Thompson and his confederates have wrestled with critics over the constitution of the early nineteenthcentury working class, the historical development of British class structure, and the theoretical problematic of culture versus structure. Much of these debates - sometimes heated and often downright scrappy has been conducted within the confines of Marxist historiography and theory, although for Thompson, at least, such controversies are always as much a matter of practical politics as the stuff of academic roundtables.

Thompson's achievements have come under renewed scrutiny recently through a new line of critique. Whereas the initial examination of The 
Making was conducted largely through the perspective of a structuralist (Althusserian) Marxism, this new critique originates in the "linguistic turn" in social theory. Drawing on deconstructionist/poststructuralist theory, both Gareth Stedman Jones and Joan Wallach Scott in particular seek to recast Thompson's analysis of class formation. $^{2}$

In this article I critically examine this "re-making" of English working class, focussing specifically on what it implies for Thompson's analysis of agency and experience in class formation, a key theoretical couplet that is sustained throughout his work. The post-structuralist critique presents a persuasive case for broadening the study of class formation by including the systematic analysis of discourse. However, I argue its proposed recentering of the analysis of class formation from a discursive perspective is a regressive exercise that undermines our understanding of agency as explicated by Thompson.

The essay is divided into four parts. First, I briefly review Thompson's use of the concepts of agency and experience. Second, I summarize the revisionist approaches of Stedman Jones and Scott, focusing on their analyses of the role of discourse in the process of class formation. Third, I critique these perspectives, arguing that they serve to obscure the role of agency and experience in class formation. Finally, I propose an alternative means by which discourse can be incorporated into Thompson's analysis.

\section{Agency and experience in The Making}

The Making is a historical panorama of class struggle and formation painted in fine brush strokes: the resilient subculture of West Riding weaving villages and the furtive machinations of London's ultra-radicals are equally illuminated with brilliance. This history, as Thompson informs us in his oft-quoted preface, is an account of how disparate groups of workers forged a class culture partly from popular traditions during their formative experiences in an emergent capitalist society. As the strokes fill the canvas of forty years the vision painted is almost always from the perspective of the terra firma of historical specificity. Thompson's purpose is to explain the "particular ways" in which outworkers, artisans, and factory workers constructed a consciousness of their own interests as opposed to the interests of those who sought to dominate them. These cultural expressions of experience are presented 
in a plethora of miniatures. In the concluding chapter, "Class Consciousness," for example, as representative experiences, practices, and actors complete the canvas, there is little that directly informs us of the overarching processes that are the foundations of his analysis.

A reading of Thompson's corpus (and of those who have sympathetically adopted his mode of class analysis) suggests that the concepts of agency and experience are at the heart of his account of class formation. Thompson's work has been a sustained reaction to both the mechanistic formalism of a "Stalinist" Marxism as well as to liberal sociological alternatives to class analysis. As opposed to these perspectives he proffers a fundamentally relational and historical understanding of class. As he states,

Class eventuates as men and women live their productive relations, and as they experience their determinate situations, within "the ensemble of social relations," with their inherited culture and expectations, and as they handle these experiences in cultural ways. ${ }^{3}$

Class is a process in which people, facing common struggles against exploitation and antagonism imposed upon them by their structural situation, create experiential and collective responses to their predicaments. In fashioning a common consciousness of their situation and a stock of cultural processes to express their resistance, class actors are active participants in the process of class formation. As he has summarily observed, "Class formations ... arise at the intersection of determination and self-activity." 4

It is precisely at this juncture that experience assumes a critical role in Thompson's scheme. People involuntarily enter into ensembles of social relationships, structured and limited by dominant forms of material life, which demand collective response. ${ }^{5}$ These relationships exert pressure on their consciousness to make cultural sense of their role and purpose in the course of life's events. Experience then is the effect of living through the process of historical relationships, common to many like-situated people. ${ }^{6}$ Importantly for Thompson, such experiences are not confined within the realm of production (i.e, the economic), nor can they be parsimoniously reduced to economic causes. Lived experience is never so tidy. Rather, it occurs wherever the friction of class interests creates the heat of conflict and discontent, and frequently this is in the sphere of politics. ${ }^{7}$ 
The other line of convergence at this intersection then is agency, i.e., the ways in which class actors respond to and make sense of these common experiences. The collective consciousness of common interests, the production of culture and systems of feeling to articulate them, and the struggles against exploitation in which they are acted upon are central to the "self-making" processes through which class formations are constituted. ${ }^{8}$ For Thompson, this conjunction between "lived" experience and agency is determinative only in the sense that it sets social forces in motion. The outcome is not teleologically overdetermined; social change is always dependent on the "class ways" in which these interests are pursued.

Change in material life determines the conditions of that struggle, and some of its character: but the particular outcome is determined only by struggle itself. This is to say that historical change eventuates, not because a given "basis" must give rise to a correspondent "superstructure," but because changes in productive relationships are experienced in social and cultural life, refracted in [peoples'] ideas and their values, and argued through in their actions, their choice and their beliefs. ${ }^{.}$

A shared sense of agency - class consciousness - is thus developed by class actors as they engage in the process of class struggle. A cultural appreciation of their own interests (as opposed to the interests of their antagonists) is produced in the process of struggle. It is often a pastiche of old cultural forms transformed and infused with new relevancy. For Thompson this too is an on-going process rather than one of finitude: history does not tip its hand to its players. To say that classes are "made" is thus misleading; instead it is more appropriate to say that they are constituted (and re-constituted), and the actors themselves always have an active hand in this process.

The roles of experience and agency in the process of class formation are why Thompson insists that class struggle is the most fundamental object of a Marxist analysis, and why "Class and class consciousness are always the last, not the first, stage in the real historical process." 10 For it is experience's fomentation of divisive interests that leads people to construct a common culture (and consciousness) of class, and in turn to seek to change their existence. In this process "class defines itself as, in fact, it eventuates." 11 Experience and agency are the essential elements that keep the process in motion.

The panoramic vision of The Making is thus a story of class formation told from the vantage of working-class people who struggled against 
the weight of economic exploitation and political oppression. These were common experiences, though they were realized in many "particular ways." Central to the telling is how people drew upon extant plebeian and radical culture, reshaping it in the process "with intelligence and moral passion" as they formulated their consciousness of class. ${ }^{12}$

Importantly, for Thompson this culture is produced in social relationships, often in the "theatre" of social struggle. The production of meaning is fundamentally behavioral and contextual: "every meaning is a meaning-in-context, and structures change while old forms may express new functions or old functions may find expression in new forms." ${ }^{13}$ This meaning thus is tethered to the actions of collective actors who produce it in the process of making experiential sense of their social relationships. Additionally, Thompson never insists that the culture of the early nineteenth-century working class was homogeneous. Instead his account is of a web of understandings within which working-class actors moved, and through which they were able to collectively construct and convey their dissatisfactions to themselves and the larger world. Their experiences were multifarious, nested in regionally distinct artisanal communities that, strung together, were the foundations of a national working class. ${ }^{14}$ As an experientially grounded culture of resistance it was in fact born of this diversity and underlying commonalities.

Finally, the casting of this process of class formation as a historically contingent process leads Thompson to reject any privileged space for this story in the general history of class formation. ${ }^{15}$ The role of agency and experience in the process foreclose the option of a teleological interpretation: class is no more or less than as its happens. Born of struggles between class actors, the histories of these struggles define class, always relationally, and always in the context of particular times and places.

\section{Stedman Jones and the analysis of radical language}

In the first round of Left critique, The Making was criticized for its overemphasis on agency and experience and an alleged sublimation of the economic and structural. None of the critics sought to confront directly the dynamic role of culture in Thompson's account. However, in several essays Gareth Stedman Jones has offered a revamped inter- 
pretation of the development of English working-class consciousness in the early nineteenth century in which the role of a crucial part of this culture, radical political discourse, is formulated in a new light. ${ }^{16}$ Through a re-examination of Chartism, a radical working-class political movement for universal suffrage stretching roughly from 18371852 , he seeks to recast the historiography of working-class formation for the period circumscribed in The Making. ${ }^{17}$

Stedman Jones contends that the historiography of Chartism (and by inference that on the early nineteenth-century working class) suffers from economistic reductionism. He charges that historians have viewed politics in general, and its discourse in particular, as epiphenomenal, and have thus misread Chartism's impetus. Although he credits Thompson for the centrality of politics in The Making, he critiques Thompson's concept of experience for posing a direct link between social being and social consciousness. Stedman Jones's solution is to propose discourse as a crucial mediating link between the two. Through discourse, experience is given political form, a conflict-oriented consciousness is fomented, and groups are wedded to programs of action. ${ }^{18}$

From the 1770 s through the Chartist decades, Stedman Jones finds a radical political discourse as the raison d'etre of working-class dissent and collective action. Founded upon Painite Republicanism, this discourse located working-class oppression in the political tyranny of the wealthy, titled, and influential. Based on a theory of natural rights and democratic constitutionalism, this radicalism argued that political representation was the solution to working-class ills. The targets of its attack shifted with changing realities and the discourse accommodated itself to competing analyses, but the political core remained steadfast. Chartism, as the apogee of this radical discourse, offered a palpable political plan, not based in class interests, to eradicate working-class misery. With state reform in the 1840 s, however, it became an outmoded interpretive scheme, eventually dissipating because of its irrelevancy. ${ }^{19}$

For Stedman Jones, then, radical discourse played the central role in the making of English working class: "Radicalism ... determined the form taken by the democratic movement." ${ }^{20}$ In this sense radical discourse was both the vehicle and the limiting factor for class agency. Class struggle was possible because working-class groups were able to translate the raw material of experience into an intelligible shared critique of their oppression as well as a program for action. Experience's 
role in the process of class is bounded by the opportunities that any given discourse presents as the essential mediator between it and consciousness. In the process of class formation, the impact of economic exploitation and political oppression becomes contingent upon cultural dynamics.

\section{Joan Wallach Scott and the gendering of class}

Where Stedman Jones brings discourse squarely into the examination of class formation, Joan Wallach Scott makes it the consuming object of analysis. Claiming to adopt methods of analysis from deconstructist and post-structuralist theory, she provides a gender-based critique of The Making. Scott contends that these theories allow historians to analyze the role of gender in the making of working-class labor, social life, and politics. ${ }^{21}$

Defining gender as the "articulation (metaphoric and institutional) in specific contexts of social understandings of sexual difference," Scott argues that it, as all meaning, is a discursive field of power. ${ }^{22}$ We experience this power through discursively constructed meaning: "Without meaning there is no experience; without processes of signification, there is no meaning." ${ }^{23}$ Experience and agency are thus actuated in discourse. It follows that the interests that motivate actors and the possibilities for social change are discursively constructed. Class thus becomes a discursive "field that always contains multiple and contested meanings." 24 As such, it is related to other categories within which actors and their interests are constituted, gender foremost among them.

In Scott's critique, Thompson's history is androcentric, ignoring the centrality of gender in the construction of class. The Making "is preeminently a story about men, and class is, in its origin and in its expression, constructed as a masculine identity, even when not all of the actors are male." ${ }^{25}$ Gendering is immanent (though sublimated) in the encoding of productive relations as masculine and of the domestic sphere as feminine. ${ }^{26}$ The "masculine" sphere of labor is seen as the fount of class consciousness. Rationalist and secular aspects of working-class radical politics are portrayed as masculine; the expressive, utopian, and spiritual are negatively constructed as feminine. ${ }^{27}$ Women are thus relegated to two secondary representations in this process: either they are part of the sphere of production, in which case they are participants in the masculine construction of class, or they are regres- 
sive elements, whose expressive nature is "a troubling exception, asserting needs and interests detrimental to class politics...." 28

By locating the dynamic of class formation in labor exploitation and rationalist radical politics, Thompson marginalizes the "feminine" in the process of class formation according to Scott. The gendering of the family division of labor, the role of the domestic sphere in the production of class meaning, and the part of spiritual and utopian ideas in the construction of class consciousness are all lost within this androcentric reading. Women themselves are presented as "only partial or imperfect political actors." 29

Scott provides no alternative reading of English working-class formation, and indeed her deconstructionist perspective should eschew any such essentialism. Rather, she challenges readers to dissect the many moments of this history in which the constitution of class was derivative of the shifting meanings of gender. By producing such accounts we will be able to understand how discourse organized lived experience, and how the agency of working-class actors was bounded and realized in the production of such meaning. ${ }^{30}$

\section{Critically appraising the "Re-Making"}

Both Stedman Jones and Scott significantly revamp The Making. While Scott provides a more radical critique, their shared emphasis on discourse leads to certain commonalties of argument. In particular, both concentrate on the role of discourse in the process of nascent class formation.

The contributions can be assessed on three distinct levels. First is the issue of their reading of The Making (and Thompson's related work): do they faithfully represent Thompson's version of class formation? Second is the question of whether these revisions have added to our understanding of class formation, building upon the advances contained in the experience/agency couplet. Do they provide theoretical gains for the analysis of class formation? Finally, these approaches can be evaluated at the level of historiography. Does Stedman Jones enhance our knowledge of radical working-class politics? Does Scott add to our comprehension of the role of women in the formation of the early nineteenth-century English working class? In each case I believe that the answers are largely negative. However, the issues they raise 
about the role of discourse are important, and should be addressed from a materialist perspective.

\section{Readings of The Making}

Both Stedman Jones and Scott offer reductionist accounts of Thompson's history, particularly the latter. Stedman Jones rightly isolates the link between experience and social consciousness as a key dynamic in The Making. However, he too readily attributes an unproblematic version of this relationship to Thompson's work. In fact, Thompson has maintained throughout that experience and the consciousness to which it gives rise exist in a complex dialectical relationship. ${ }^{31}$ The link between the two is never simply referential. Indeed, one of the principal achievements of The Making is the detailing of the ways in which working-class groups fashioned an oppositional consciousness out of manifold elements of plebeian politics and culture. Undergirded by a Gramscian sense of cultural struggle, Thompson has always taken this to be a central problematic in his analysis of class formation.

It is Scott, however, who provides the more reductionist version of Thompson's panorama. Her portrayal misrepresents The Making on at least three themes: the unity of working-class culture, the essentially masculine, rationalist form in which it is depicted, and the role of the domestic in its development. On the first issue Scott contends that Thompson depicts the growth of a working-class culture in "unified terms," in which he assumes "some exact fit between material life and political thought" rather than examining its diversity. Thompson does not systematically examine the connections between the various strands of working-class culture which he charts, and there remains theoretical and historical space to explore the ways in which these strands were able to construct a unifying experience of exploitation and oppression. However, as I have noted, he never insists upon a unilinear conception of working-class culture, and the many facets of it explored in The Making are clear evidence of this. ${ }^{32}$

In her critique of Thompson's version of working-class radicalism as masculine and rationalist, and of the chiliastic religion of the period as feminine, Scott presents a clean fissure in working-class culture where Thompson finds many jagged edges. While he maintains a central role for the rationalist and Enlightenment traditions (including, of course, Mary Wollstonecraft, along with Paine and Godwin), Thompson never 
loses sight of the other elements of plebeian culture that workers drew on in constructing a class consciousness. In the closing pages of The Making he observes that,

...it is premature, in the 1830 s, to think of the English working people as being wholly open to secular ideology. The Radical culture which we have examined was the culture of skilled men, artisans, and of some outworkers. Beneath this culture (or co-existing with it) there were more obscure levels of response, from which the charismatic leaders like Oastler and O'Connor drew some of their support. ${ }^{3.3}$

Finally, Scott misrepresents Thompson's characterization of the domestic sphere. The Making is clearly deficient in its analysis of domesticity, yet this absence does not necessarily lead to the conclusion that it was a "place from which politics cannot emanate because it does not provide the experience of exploitation that contains with it the possibility of the collective identity of interest that is class consciousness...." ${ }^{34}$ Thompson does understand the domestic sphere to be a place crucial to the organic production of a working-class culture and as a site where exploitation was acutely experienced. ${ }^{35}$ However, his analysis centers on the exploitation of the domestic unit - not women and this omission needs correction.

\section{The analysis of class formation: Agency and experience}

These misrepresentations of The Making are grounded in alternative theoretical approaches to the roles of agency and experience in class formation. As we have seen, Thompson's achievement has been to show that class actors are not simply moved imperiously by structure, but have an active hand in their making. However, in their revisionism both Stedman Jones and Scott construct a neo-structuralism of discourse in which language is invested with imperial ascendancy, and actors have diminished agency.

While for Stedman Jones experience remains the bedrock for action, discourse becomes its grand interpreter, inscribing meaning on the lessons that experience renders. Initially it appears as a window of interpretability and a means of setting an agenda for action; yet this supporting role is quickly transformed into the impressario of the class process. Discourse exists outside of the dynamics of ongoing social and political life, rather than in a dialectic relationship with experience (as culture does for Thompson). It mysteriously manages to accommodate 
itself to the change, yet its structure is never fundamentally threatened by changes in material life. As such, discourse seems to be autogenic, requiring neither experience nor any other facet of social life for its continuity. In the end it imposes a structure on class action.

If in Stedman Jones's formulation experience is a servant of discourse, within Scott's deconstructionist perspective neither experience nor agency have substantive roles. For Scott, experience has no reality outside of its signification. ${ }^{36}$

Its apprehension is reduced to a radically temporalized form, dependent on context-driven processes of meaning production. Experience is a marginalized process of iterated, and perhaps not cumulated episodes. ${ }^{37}$

Though Scott specifically argues for a concept of agency in this discursively constructed world, it is essentially stillborn given her epistemological foundation. ${ }^{38}$ It is precisely in the discursive construction of the subject that deconstructionism and its allied post-modern philosophies deny agency in subjectivity. With consciousness and interests a product of discourse, it would seem that the agendas of class (and gendered) actors are given and not devised. Discourse operates largely as a structural constraint, rather than a facilitator for collective action or social change. ${ }^{39}$

If we accept Thompson's perspective on class formation as an advance over more structural theories, then the discursive turn of Stedman Jones and Scott is largely regressive. Within their analysis we lose sight of the role of class actors in the making of class formations. Discourse dictates world views, channels collective action, and itself becomes the motor of change.

Moreover, even if we were to accept these discursive perspectives, we are left with virtually no understanding of the dynamics of discourse or the social change it produces. In the case of Stedman Jones, political radicalism is a pre-given entity. Its mutations to accommodate new working-class trials and experiences are noted but never wholly analyzed, and the underlying mechanisms for its success and failure remain obscure throughout. For Scott, change is an inherent and endemic feature of discourse because of its essential polysemy. This deconstructionist vision of change, however, is essentially a synchronic understanding of many moments, in which the diachronic links are never 
adequately explicated. Within the discursive field the "supplement" of meaning of any signifier lurks in the shadows, waiting to deny any fixity of meaning. Scott does not actually address the process of class formation, and even the gendering of class actors (and action) itself is an enigmatic process. ${ }^{40}$

\section{Failed revisions of politics and gender}

Within each critique of The Making an analytic theme is used as the scalpel for dissecting Thompson's vision of class formation. For Stedman Jones, this theme is radical politics; for Scott, it is the process of gendering. Renderings of each theme within a discursive perspective are taken to highlight the failures of Thompson's approach and to recast the analysis of class formation. However, by proffering discourse as the singular explanans of class formation they succeed only in impoverishing both Thompson's account and their alternatives.

In The Languages of Class, Stedman Jones seeks to discern the ways in which meanings contained in political language forge a consciousness of power relations and class. Within this formulation the lessons of experience are never simply conveyed through language, nor do they necessarily cumulate as class consciousness. Rather, class and interest are taken to be discursive constructs. Discourse manufactures and orchestrates demands, collective identifications, and the need for collective action and redress. ${ }^{41}$

While Stedman Jones isolates an important problematic, his singular emphasis on the production of meaning reduces politics to a language game. Politics devolves into the grand art of persuasion. Ultimately, the boundaries and constitution of the political themselves become hopelessly muddled in the anterior dynamics of discourse. There is no coherent explanation for why actors would seek to politicize a facet of the social world, accept a particular vision of the political over competing forms, or even how actors have autonomy to effect transformations within these discursively given perceptions. Such explanations require recourse to non-discursive forces which have little causal role within his perspective. As a result, we lose sight of the role of politics in the process of class formation. In a world produced by discourse there is no clear demarcation between class and politics, and no sure means of distinguishing the causal connections between them. ${ }^{42}$ 
For Scott, deconstruction leads to a neglect of the particular experiences of women in class formation, the possibilities of greater gender parity at junctures in the process, and a paradoxical essentialism. On the first point, Judith Bennett observes that Scott's concentration upon meaning creates a myopic disregard for women's lives.

\begin{abstract}
Pursued on its own, the Scottian study of gender ignores women qua women (a subject that still deserves greater attention); it evinces very little interest in material reality (focusing on symbols and metaphors rather than experience); and it intellectualizes and abstracts the inequality of the sexes. The hard lives of women in the past; the material forces that shaped and constrained women's activities; the ways that women coped with challenges and obstacles - all of these things can too easily disappear from a history of gender as meaning. ${ }^{43}$
\end{abstract}

Period histories still include precious little on women's roles in the organization of domestic production, degraded trades, and on women's trade societies. ${ }^{44}$ More importantly, as Maxine Berg has observed, women formed crucial links among domestic production, consumption and community networks, links vital to the process of class formation. ${ }^{45}$ Arguing that historians summarily define production as "masculine" does little to advance our knowledge of the contributions and experiences of women in these areas, while it tends to deflect attention from them and toward those spheres of life supposedly encoded as "feminine." Indeed, an important missing piece in The Making is a full explanation of how degradation of trades and gendering were intertwined in the capitalist transformation of domestic production. ${ }^{46}$

Just as significantly, Scott's emphasis on difference and meaning deflects attention from the possibilities of increasing gender parity within the sweated trades during the period. Degradation was a great leveller, and both women and men in the sweated trades of the period shared the experience of exploitation. There is no disputing the argument that any trade that was seen as "women's work" was also viewed as degraded, nor that much of the wage work performed by women continued to be segregated. However, the possibility of a lessening of differences due to the importance of women' wage labor to the household economy and their entrance into degraded (and previously male) occupations also require greater scrutiny. ${ }^{47}$

Much the same can be said of the contributions of women in politics and protest. As Sonya Rose has noted, a great deal of the work in these areas has focused on women's participation as an extension of their 
domestic roles. Even though their public participation became increasingly marginalized with the growing formalization of working-class protest, women doubtless continued to shape ideas on justice, equality, and mutuality central to working-class politics. ${ }^{48}$

Finally, Scott's reading of The Making and the period's history at times seems to take on an essentialism contrary both to her deconstructionism and the complexities of the history itself. This is so in two respects. First, while criticizing Thompson and other Marxist historians for myopic visions of the development of industrial capitalism, she offers a perspective that appears equally partial: “...the sexual division of labor, oppositions between work and family, household and workplace, men and women, are what capitalism itself is all about." ${ }^{49}$ There is no question that the development of capitalism is about such matters. However, it is not all about them, any more than the transformation of the labor process or the development of new class structures are our sole foci of analysis.

Second, Scott argues that Thompson and other social historians treat what is coded as "feminine," as marginalized or excluded. However, many historians have noted that the feminine at times had positive significant social connotations. One striking example is the widespread use of cross-dressing by male protesters. Male outworkers dressed as women were not unusual features of protest involving the destruction of machinery, as in the Luddite and Swing protests. Additionally, the female image as a character of justice, as in the case of the Rebecca riots, suggests another such construction. ${ }^{50}$ These histories then do illustrate that the "feminine" could contain positive, even heroic, meanings, and that gendering, as class, was a complex and context-dependent process. ${ }^{51}$

In summary, while both Stedman Jones and Scott seek to add new dimensions to the analysis of class formation, their efforts fall short. Under the encompassing perspectives of politics and gender, class formation itself is obscured and the history reified. Discourse becomes singularly causal, while the many facets of social life that constitute lived experience are reduced to a system of meaning. However, experience is never so singular as to be captured within the confines of one abstraction. What we need, and what the post-structuralists lack, is a way of tying discourse to the complex processes of class formation, showing how it is a mediating process. In the final section below, I suggest some ways which this may be accomplished. 


\section{Bringing in discourse}

Regardless of their inadequacies, Stedman Jones and Scott have pinpointed an important problem in The Making. Through radical discourses working-class actors become conscious of their positions, interests, and agency. For Thompson the radical press offered a window on class subjectivity, revealing commonalties between people in both the pain of exploitation and the desire for redress. ${ }^{52}$ Yet despite its centrality in the chronicle, the causality of discourse is enigmatic.

Within materialist approaches to language, however, we can find a theoretical framework that ties discourse to Thompson's understanding of class formation. The starting point is Stedman Jones's initial observation - that discourse mediates between experience and consciousness. From this point, we can show how discourse serves to mediate experience on the one hand, and on the other, the degree to which it affects agency in the process of class struggle.

Contrary to the post-structuralist viewpoint, materialist theories assert that people bring experiences to discourse, i.e., that material social life has an apprehended existence prior to its discursive framing. ${ }^{53}$ Indeed, materialist theories argue that discourse exists as a process because the other material/social processes in which people engage beg a larger symbolic ordering. Discourse is the process through which actors create propositional or evaluative accounts of the relations between themselves, other actors and situations, and larger social processes. Actors and contexts are historically and reciprocally tied together in the process. The process of meaning production is itself always governed by systems of rules delineating the use of the symbols that convey meanings (signifiers), the meaning attributed to them, and restrictions on those who engage in the process. Discourse is thus viewed as a productive process, with certain homologies to other forms of production. $^{54}$

As the production of social meaning, discourse is an ideological process. It is ideological because it is through discourse that we provide (a) generalized maps of relations among actors, contexts, and activities, (b) evaluative frames for these, and (c) possibilities for alternative social relations and situations. ${ }^{55}$ By linking diverse situations through discourse we construct collective and supra-contextual ideological frames for experience. 
Discourse can also be a hegemonic process because it orders collective understandings of the world in particular ways, privileging some meanings and precluding others that are potentially subversive. Additionally, its rules can legitimate some actors and proscribe others from participation in the process of meaning production. In all of the above ways, we may conceive of discourse (in part) as a lynchpin in a Gramscian ideological "war of position" in class formation. Contests are waged over the control of meaning production and, with it, ideological ascendancy. ${ }^{56}$

Since discourse largely is produced in social routines, we can see partially recurrent patterns arising within its production, which I term discourse streams. This patterning over time creates sets of streams that are tied to particular institutional and social spheres. Actors use these streams to structure plausible accounts of situations and activities. For any given historical period and for particular social and institutional contexts there are a limited number of such streams through which actors can structure accounts. Contrary to post-structuralist theory, there are limits to the variability of this meaning imposed by the social and material world (an object of analysis fundamentally different from a literary text). These limits mark the number of plausible streams and structure the discursive field within which actors produce meaning.

It is in the use of streams to construct meaning where we find agency tied to experience in class formation. Discourse, while bounded, is never simply referential. Its polysemy leaves it open to alternative (and sometimes conflicting) interpretations. Further, the semiotic manipulations of streams leaves them open for appropriation and transformation for use in different contexts from those of their origins. Thus we find agency in the ways class actors are able to dominate the use of streams within a discursive field to structure and articulate their views of the world. The discursive boundaries imposed on this agency are those where issues of intelligibility and comprehensibility arise. When actors produce meaning through discourse streams they are at once constructing a set of collective interests, as well as defining potentially oppositional meanings and interests. Is is in this sense that we find a "war of position."

Finally, discourse is a process tied to forms of social organization and action, institutional contexts, and collective resources. The availability of streams is crucially dependent on the networks that compose a collectivity, its ties to other groups and access to social spheres, and the 
resources it has both to survey and appropriate streams in a discursive field and disseminate proffered meanings. Parallel to Thompson's concept of culture, discourse in this formulation is a process of collective activity. ${ }^{57}$

In terms of the process of class formation then, discourse can be conceptualized best as the process that bounds possibilities for collective perceptions of class structure and struggle. It mediates the way in which groups experience and react to the material and social forces that animate class formation. This is noted most easily in the sphere of ideology and other forms of cultural production, in which collective actors make sense of their experience.

Returning to The Making we can see how in Thompson's history this process was repeated among numerous working-class groups across both time and nation. Through printed word (particularly the "unstamped" press) and oral tradition, and within political and trade organizations, the working-class was provided with a series of discourse streams through which they framed their interests and those of their antagonists. As Stedman Jones correctly asserts, these streams mediated between collective experience and consciousness. In this process working-class groups exercised agency in constructing understandings of their dilemmas. Discourse translated experience, informed context, and posed possibilities. However, it did not impose grievances, paths of redress, or class consciousness.

The underlying importance of discourse may be appreciated from the start of The Making in Thompson's emphasis on the importance of the London Corresponding Society. The idea of "members unlimited" was not only important for working-class organization, it was equally important for the production of working-class discourse. The various societies and committees that dot the subsequent course of Thompson's panorama are consequential in the same sense, for they all provided crucial social venues and organization within which the production of discourse occurred.

As important (if not more so) were the many organs of working-class expression that figure so prominently in Thompson's account. They can be conceived as having provided the partially processed materiel sets of signifiers and meanings - through which working-class collectivities produced a consciousness of class. Cobbett and Carlile, Hunt and Hetherington, Owen and O'Brien, all are crucial in The Making 
because they provided the working class with discourse streams through which they could articulate their senses of oppression and exploitation. Periodicals such as the Political Register, The Republican, The Poor Man's Guardian, as well as the myriad pamphlets that were the staple fare of hawkers, provided archetypal streams that were appropriated to express class consciousness in the "particular ways" in which experience begged. They provided palpable models of the world, which working-class groups refined and reformulated to reflect their local exigencies and experiences. Through indigenous organization and collective action these formulations served as a collective voice.

The Making then is partly a history of class agency through discourse and of discursive transformation itself. What it is not is the history of a single class discourse, if by that we conceive of a unitary, internally coherent discourse stream (much as Stedman Jones's political radicalism). Instead we find many intertwined streams, whose uses varied by locale and group. The Enlightenment rationalism of a Paine or Carlile was often found together with the utopian visions of a Spence or Owen. As they were appropriated, many such streams were refashioned in context to illuminate local experiences. An appreciation of their use requires a firm grounding in these contexts. Thus, we should envision these streams as operating in "class ways" not because of their signifiers or specific meanings, but because of the processes by which workingclass actors employed them. In the sharing of streams across groups, contexts, and locales successively larger, working-class collectivities were included within their systems of meanings.

An equally central part of this history was the process of discourse use as class struggle. Bourgeois and aristocratic groups also jockeyed within discursive fields for ascendancy. Paternalism and Political Economy were but two such streams often used to proffer visions of the world, and they themselves were subject to working-class appropriation in particular contexts. The latter, a protean discourse in its halcyon days, was a stream whose want of exactitude dismayed its practitioners, and left it open as a terrain of discursive class struggle. While Adam Smith was invoked by capital to justify free markets and unfettered competition, he was also cited by workers to legitimize their claims for high wages, a fair share of production, and the legacy of the worker to "live by his labor." In purveying popular Political Economy to the working classes, its champions frequently found that their attempts at suasion were turned into something alien to their designs. ${ }^{58}$ Religious 
discourses, often one of the mainstays of attempts to "civilize" the working classes, also composed a contested discursive field. ${ }^{59}$

Through this conceptualization we can see that the challenge posed by The Making is to obtain a better appreciation for the ways in which discourse both facilitated and limited working-class agency. This is the case in at least two senses, both of which are lacking in Thompson's panorama. First, we need detailed analyses of the ways in which working-class groups conducted discursive struggles on the local level. This includes both their decisions and actions in structuring a collective voice within the discursive fields available to them, and the ways their discourse helped to orient subsequent collective actions. Second, we need further research on how groups bridged such locally produced structures of meaning, to create larger frameworks for understanding and articulating their senses of oppression and redress in regional and national contexts. ${ }^{60}$

Thus, we should view The Making as a vital first step in the analysis of the ways in which discourse mattered in class formation. Thompson is clearly sensitive to its role in the culture of the working class, though he does not explicitly focus upon it. Further investigating the role of discourse should extend the genius of Thompson's analysis.

\section{Conclusion}

More than twenty-five years after its publication The Making of the English Working Class remains a landmark work in English history and the study of class formation. Thompson's formulation and application of agency and experience in understanding the process of class formation have altered the ways historians and social scientists approach the study of class. From its inception The Making has been a lightening rod for criticism, some of it piquant and politically charged. In the latest round of critique, Gareth Stedman Jones and Joan Wallach Scott have argued that Thompson seriously neglects the role of discourse in class formation, and in doing so has presented a partial and distorted picture. They each have offered analyses that find a central role for discourse in the process of class formation. Stedman Jones sees political radicalism as a guiding force of working-class collective action, while Scott finds a fundamental gendering of the ways in which the working class was organized through discourse. 
Both Stedman Jones and Scott are clearly correct in observing that discourse played an important role in this working-class history, yet their accounts are reductionist and highly skewed interpretations of a rich and complex history. By privileging discourse as a casual force in class formation they shunt experience and agency into minor roles, providing impoverished accounts of how the working class was indeed active in its own making.

The alternative I have proposed is to focus on discourse as an intermediate process linking experience and agency, animated through social organization and collective action. The English working class of the early nineteenth century faced degradation of their labor and political oppression of rights they perceived as fundamental. In response to these trials they constructed expressions of their grievances and visions of solutions through the discourse streams available to them. Through the contextual use of various streams they articulated a consciousness of class. This process itself was part of the class struggle that was their making. In this sense, discourse framed the painting of the panorama, and perhaps added shading, hue, and perspective, but it did not create the picture. As Thompson, following Marx, has observed, it is people that do the making, even if it is not just as they please.

\section{Acknowledgments}

This article is a radically revised version of a paper delivered at the 1989 American Sociological Association meeting. My thanks are due to Randy Ernest, Howard Kimeldorf, Irene Padavic, Sonya O. Rose, Margaret Somers, and the Theory and Society Editors for their very helpful comments on several different drafts.

\section{Notes}

1. "Socialist Humanism: An Epistle to the Philistines," New Reasoner, 1 (1957) 122.

2. Critique of Thompson's work is still being carried out within the confines of a materialist perspective. Julia Swindel and Lisa Jardine question Thompson's attention to the gender question in What's Left: Women and Culture in the Labour Movement (London: Routledge, 1990), a socialist-feminist analysis of the failings of the British Left. In addition, many of the articles in Harvey J. Kaye and Keith McClelland, editors, E. P. Thompson: Critical Perspectives (Philadelphia: Temple University Press, 1990) contain sympathetic Marxist critiques. However, the post-structuralist attack represents a more radical revisionist challenge to Thompson's work. 
3. "Eighteenth-Century English Society: Class Struggle Without Class?" Social History 3 (1978) 250.

4. The Poverty of Theory and Other Essays (New York: Monthly Review Press, 1978), 106.

5. For Thompson, despite accusations of voluntarism by his critics, the mode and social relations of production are determinate forces in this process. They provide the fundamental parameters through which experience is lived out, though they do not predestine the actual content of these experiences nor their outcome, "Folklore, Anthropology, and Social History," Indian Historial Review 3 (1977) 264.

6. Many of Thompson's critics have argued erroneously that he views experience as social perceptions. Ellen Meiksins Wood rightly counters that Thompson defines experience as the material and historical aspect of social being that germinates class consciousness as people grapple with their class situations. "The Politics of Theory and the Concept of Class: E. P. Thompson and His Critics," Studies in Political Economy 9 (1982) 49.

7. "Peculiarities of the English," in The Poverty of Theory and Other Essays (New York: Monthly Review Press, 1978), 296.

8. "Poverty of Theory or an Orrery of Errors," in ibid., 107.

9. "Folklore, Anthropology, and Social History," 266.

10. "The Poverty of Theory," 149.

11. "Eighteenth Century English Society," 150.

12. The Making of the English Working Class (New York: Vintage, 1966), 832.

13. "Folklore, Anthropology, and Social History," 256.

14. The Making, 471, 611, 719.

15. "Eighteenth Century English Society," 150.

16. Stedman Jones has published both a short and a long version. The short version is "The Language of Chartism," in James Epstein and Dorothy Thompson, editors, The Chartist Experience: Studies in Working-Class Radicalism and Culture. 1830 1860. (London: Macmillan, 1982), 3-58. The longer version is "Rethinking Chartism" in his volume The Languages of Class: Studies in English Working Class History 1832-1982 (Cambridge: Cambridge University Press, 1983) 90 178.

17. The rubric Chartism was derived from the plank of demands that were established in the early phases of the agitation in 1838 . The bedrock of Chartism was the Charter, six demands for the radical reformation of the political system. The six "points" of the Charter were universal male suffrage, annual Parliaments, equal electoral districts, vote by secret ballot, salaried representatives (MPs), and the eradication of property qualifications for office holding. As a movement encompassing more than a decade of agitation, there were of course a variety of other political and economic platforms that ebbed and flowed during its course. The Charter was, however, the one element of constancy that survived the entire period and one that had national adherence. For recent histories of the movement, see Dorothy Thompson, The Chartists (New York: Pantheon, 1984), James Epstein, The Lion of Freedom: Feargus O'Connor and the Chartist Movement (London: Croom Helm, 1982), Epstein and Thompson, editors, The Chartist Experience, and John Saville 1848: The British State and the Chartist Movement (Cambridge: Cambridge University Press, 1987).

18. "Rethinking Chartism," 93-94, 96, 99, 101.

19. Ibid.

20. Ibid., 126 
21. "On Language, Gender, and Working-Class History," International Labor and Working-Class History 31 (1987), 2-3.

22. Ibid., 2. Scott describes gender as having four constituent elements: its symbolic representation, the normative concepts used to interpret them, their politics within social institutions and organizations, and its existence as a subjective identity, "Gender: A Useful Category of Historical Analysis," in Gender and the Politics of History (New York: Columbia University Press, 1988), 43-44.

23. Ibid., 38.

24. "Women in The Making of the English Working Class" in Gender, 88.

25. Ibid., 72. See also "Gender: A Useful Category," 48. This criticism applies more generally to all Marxist analyses: "within Marxism, the concept of gender has long been treated as the by-product of changing economic structures; gender has had no independent analytic status of its own," "Gender: A Useful Category," 36, see also "Women in The Making." See also Joan Scott "the Problem of Invisibility." in Jay Kleinberg, editor, Retrieving Women's History: Changing Perceptions of the Role of Women in Politics and Society (Oxford: Berg and UNESCO, 1989), 14.

26. "Women in The Making," 69, 73, 79.

27. Ibid., 76, 78-79; "On Language, Gender, and Working-Class History," 9.

28. Ibid., 10 .

29. "Women in The Making," 73.

30. Ibid., 88-89.

31. See for example his "The Politics of Theory," in Raphael Samuel, editor, People's History and Socialist Theory (London: Routledge \& Kegan Paul, 1981), 398.

32. Scott in fact hedges on this assertion. For example, she notes that "it is the articulation of the experience that varies according to culture, time and place," and that "Thompson insisted that the terms used to express the idea of class were relative to time and place" ("Women in The Making," 69, 89).

33. The Making, 802. It is particularly on the issue of rationalist politics versus spiritualism that Scott distorts Thompson's position. She states that "He depicts rationalist, secular politics as the only possible form of class consciousness, thereby making its appearance natural or inevitable, instead of the product of struggle or debate" ("Women in The Making," 76, emphasis added). This leads her to contend that religion is the feminine antithesis of politics (a peculiarly essentialist statement for a deconstructionist). However, Thompson never draws such a neat distinction, and at times is at pains to examine how the two coalesce at specific junctures. In his summation of Owenism, for instance, he observes that "Mr. Owen, the Philanthropist, threw the mantle of Joanna Southcott across his shoulders. The tone of the ranter was noted not only by Hazlitt, but by others of his contemporaries" (The Making, 787).

34. "Women in The Making," 73.

35. Radical politics had clear domestic roots in Thompson's depiction. It was at the hearth where children were steeped in its ideology and tradition, the "really useful knowledge" lauded by working-class writers. Thompson, for example, quotes the radical James Watson as remembering "my mother being in the habit of reading Cobbett's Register, and saying she wondered people spoke so much against it; she saw nothing bad in it, and many good things in it" (The Making, 755). Thompson has also noted the role of women in rioting, particularly food rioting because of their keen sense of market exploitation ("The Moral Economy of the Crowd in the Eighteenth Century," Past and Present, 50 (1968) 115-116).

36. "Gender: A Useful Category," 38. 
37. For a similar critique, see Bryan D. Palmer, Descent Into Discourse (Philadelphia: Temple University Press, 1990) 78-86. For a feminist perspective on this issue, see Susan Bordo "Feminism, Postmodernism and Gender-Scepticism," in Linda J. Nicholson, editor, Feminism/Postmodernism (London: Routledge, 1990), 149.

38. On the issue of agency she states that, "Within these processes and structures there is room for a concept of human agency as the attempt (at least partially rational) to construct an identity, a life, a set of relationships, a society within certain limits and with language - conceptual language that at once sets boundaries and contains the possibility for negation, resistance, reinterpretation, the play of metaphoric invention and imagination ("Gender: A Useful Category," 42).

39. "Introduction," in Gender and the Politics of History, 5. For feminist critiques of Deconstructionist epistemology see Linda Alcoff, "Cultural Feminism versus PostStructuralism: The Identity Crisis in Feminist Theory," Signs 13 (1988) 416-417, and Mary Poove, "Feminism and Deconstructionism," Feminist Studies 14 (1988) 52. For critique on the historiographic side, see Louise Tilly "Gender, Women's Historiography, and Social History," Social Science History, 13 (1989) 452, and Myra Jehlen's comments in Jane Caplan et al., editors, "Patrolling the Borders: Feminist Historiography and the New Historicism," Radical History Review, 43 (1989) 34-35.

40. In her response to Scott's critique of Stedman Jones, Christine Stansell offers a similar line of criticism, arguing that Scott's post-structuralism tends toward "the flip side of crude materialism" ("Response to Scott," International Labor and WorkingClass History, 31 (1987) 28).

41. Languages of Class, $8,19,20-24$.

42. For recent trenchant critiques of Post-Structuralist difficulties with politics, see Palmer, Descent Into Discourse; Nancy Fraser, Unruly Practices: Power, Discourse and Gender in Contemporary Social Theory (Minneapolis: University of Minnesota Press, 1989) ch. 4; and Eleanor MacDonald "Derrida and the Politics of Interpretation," in Ralph Miliband et al,, editors, Socialist Register 1990 (London: The Merlin Press, 1990) 228-243.

43. "Feminism and History," Gender and History, 1 (1989) 258.

44. For two recent papers that survey the advances in these areas over the last 15 years see Maxine Berg "Women's Work, Mechanization and the Early Phases of Industrialization in England," in Patrick Joyce, editors, The Historical Meanings of Work (Cambridge: Cambridge University Press, 1988), 64-98, and Sonya O. Rose "'Gender at Work': Sex, Class and Industrial Capitalism," History Workshop 21 (1986) 113-131. Scott herself has recently commented on the problem of the invisibility of women in this history ("The Problem of Invisibility").

45. Berg, "Women's Work," 95.

46. Sally Alexander "Women, Class and Sexual Differences in the 1830s and 1840s: Some Reflections on the Writing of Feminist History," History Workshop 17 (1984). The Making is clearly deficient on these grounds, though Thompson does briefly remark upon the effect of the transformation of production in the lives of women (The Making, 413-415). For a Thompsonian perspective on the gender/ class link, see Alice Kessler-Harris, "A New Agenda for American Labor History," in J. Carol Moody and Alice Kessler-Harris, editors, Perspectives in American Labor History: The Problems of Synthesis (DeKalb: Northern Illinois University Press, 1989), 226.

47. See Sally Alexander "Women's Work in Nineteenth-Century London: A Study of the Years 1820-50," in Juliet Mitchell and Ann Oakley, editors, The Rights and 
Wrongs of Women (Harmondsworth: Penguin, 1976), 59-111; Maxine Berg, "Women's Work"; Duncan Bythell, The Sweated Trades (New York: St. Martin's, 1978); Ruth Smith and Deborah Valenze, "Mutuality and Marginality: Liberal Moral Theory and Working-Class Women in Nineteenth-Century England," Signs 13 (1988), 288; Louise Tilly and Joan Scott, Women, Work and Family (New York: Holt, Reinhart \& Winston, 1978).

48. Rose, "Gender at Work," 122. See also John Bohstedt, "Gender, Household and Community Politics: Women in English Riots 1790-1810," Past and Present 120 (1988) 88-122; David J. V. Jones, "Women and Chartism," History, 68 (193) 1-21; Iain McCalman, "Females, Feminism and Free Love in an Early Nineteenth Century Radical Movement," Labour History 38 (1980) 1-25; Barbara Taylor, Eve and the New Jerusalem (New York: Pantheon, 1983); Dorothy Thompson, The Chartists (New York: Pantheon, 1984) ch. 4; E. P. Thompson "The Moral Economy"; Malcolm I. Thomis and Jennifer Grimmet, Women in Protest 1800-1850 (London: Croom Helm, 1980); and Deborah Valenze, Prophetic Sons and Daughters: Female Preaching and Popular Religion in the Industrial Revolution (Princeton: Princeton University Press, 1985).

49. Elaine Abelson, et al. "Interview," 48.

50. Thomis and Grimmett, Women in Protest, ch. 7. See also David J. V. Jones, Rebecca's Children: A Study of Rural Society, Crime, and Protest (Oxford: Oxford University Press, 1990); Frank Peel, The Rising of the Luddites, Chartists and PlugDrawers, 4th ed. (New York: August M. Kelly, 1968).

51. As Barbara Taylor argues, the image of femininity had ambiguous connotations: "The notion that women had a unique moral mission to perform was popular among all kinds of people in the early nineteenth century, anti-feminist as well as feminist. Its ideological function was highly ambiguous" (Eve and the New Jerusalem, 30). Other political protests, particularly the Queen Caroline Affair, may also show positive meanings attached to the "feminine." See Thomas Lacquer "The Queen Caroline Affair: Politics as Art in the Reign of George IV," Journal of Modern History 54 (1982) 417-466; Iowerth Prothero, Artisans and Politics in Early Nineteenth-Century London (London: Methuen, 1979), ch. 7.

52. See, for example, The Making, 674.

53. Len Doyal and Roger Harris, "The Practical Foundations of Human Understanding," New Left Review 139 (1983) 59-78.

54. Robert Hodge and Gunther Kress, Social Semiotics (Ithaca: Cornell University Press, 1988). See also Ferrucio Rossi-Landi, Language as Work and Trade: $A$ Semiotic Homology for Linguistics and Economics (South Hadley, MA: Bergin \& Garvey, 1983), and V. N. Volosinov, Marxism and the Philosophy of Language (Cambridge: Harvard University Press, 1986).

55. Goran Therborn, The Ideology of Power and the Power of Ideology (London: Verso, 1980), 18. See also John B. Thompson, "Language and Ideology: A Framework for Analysis," Sociological Review 35 (1987) 516-536.

56. Chantal Mouffe, "Hegemony and Ideology in Gramsci," in Mouffe, editor, Gramsci and Marxist Theory (London: Routledge and Kegan Paul, 1979) 192. See also Lawrence Grossberg "Strategies of Marxist Cultural Interpretation," Critical Studies in Mass Communication 1 (1984) 392-421; Leonardo Salamini "Gramsci and the Marxist Sociology of Language," International Journal of the Sociology of Language 32 (1981) 27-44; and Raymond Williams, Marxism and Literature (Oxford: Oxford University Press, 1976).

57. Volosinov, Marxism and the Philosophy of Language. See also, Robert Wuthnow, 
Communities of Discourse: Ideology and Social Structure in the Reformation, the Enlightenment, and European Socialism (Cambridge: Harvard University Press, 1989).

58. See, for example, Gregory Claeys's analysis of "productive" versus "unproductive" labor ("The Reaction to Political Radicalism and the Popularization of Political Economy in Early Nineteenth-Century England," in Terry Shinn and Richard Whitley, editors, Expository Science: Forms and Functions of Popularization (Dordrecht: D. Reidel, 1985), 119-136), as well as Max Goldstrom's discussion of the popularization of Political Economy (ibid., 259-273). As Claeys observes, propagandists found themselves in a protracted struggle up until about the midcentury in achieving hegemony through the discourse of Political Economy (ibid., 133). Noel Thompson in his provocative discussion of "Smithian socialism" presents many insights along these lines (The People's Science: The Popular Political Economy of Exploitation and Crisis 1816-34, (Cambridge: Cambridge University Press, 1984).

59. For discussions of Christian Socialism during the first half of the century, see Eric J. Hobsbawm, Primitive Rebels: Studies in Archaic Forms of Social Movements in the 19th and 20th Centuries (New York: Norton, 1959), and John Saville "The Christian Socialists of 1848" in John Saville, editor, Democracy and the Labour Movement (London: Lawrence Wishart, 1954), 135-159. For a recent analysis of populist preachers, see Valenze, Prophetic Sons and Daughters.

60. My analysis of the discourse and collective action of the Spitalfields silk weavers and cotton spinners of Ashton-under-Lyne and Stalybridge addresses some of these issues (Worthy of Hire: Discourse, Ideology and Collective Action Among English Working-Class Trade Groups, 1800-1830, unpublished Phd. dissertation, University of Michigan, 1989, 2 v.). 